\title{
A Maiden of Nobility Manor and Nihilism: Some Remarks on the Nineteenth Century Feminist Movements in Poland
}

Iwona Węgrzyn

Jagiellonian University Poland, Poland

\section{Abstract}

This article is focused on specific aspect of the history of Polish women emancipation movement - abandonment by young noblewomen conservative tradition in which they were raised in favour of some ideas of the nihilism.

Because of Russian origins of nihilism Modernity and the struggle for women's rights was considered to be a threat to national identity and fight for independence.

On the base of literary portrait of Sonia from Kraszewski's novel "Szalona" I would like to present forgotten radical branch of Polish 19th century feminism. I want to show this phenomenon in context of and in contrast to the Polish mainstream culture.

Keywords: 19th century feminism, women emancipation movement, conservatism, Polish national identity, gentry tradition

A statement that in Polish nineteenth century literature there was no great female characters is rather a commonplace. This striking lack of any convincing female characters has already been stressed by Polish great Romantic poet Cyprian Kamil Norwid, or the columnist female writers within the "enthusiast" milieus - the first Polish emancipationists (the 1840s), yet first of all, the shortage of the 
Polish nineteenth-century "herstory" appears to be a serious concern of the contemporary scholars representing gender studies ${ }^{1}$.

It is beyond all doubt that in the $19^{\text {th }}$ century the heroes of our national collective imagination were men - the participants of the independence struggles: leaders, soldiers and conspirators, as well as Romantic geniuses, poets and prose writers. Even if there are women within this group (such as Mickiewicz's Grażyna or the heroine of Śmierć pułkownika [Death of a Colonel] - Emilia Plater), their artistic presentation turn out to be some variation on male social functions, knightly ethos and patriotic duty. The femininity of those heroines is merely a fault - their weakness, sensitivity or shyness has to be overcome so that they could reach the desired aim. Their physicality, sexuality is simply unmentioned. The situation is similar with female writings of that period - the multitude of female writers (and there were surprisingly many women who wrote) is absolutely not translated into the recognition of their literary output, nor to the distinct specification of their character or style. The most distinguished female writer of the first half of the $19^{\text {th }}$ century - Narcyza Żmichowska - poses a question which is by no means theoretical: can a woman be a poet? So far any such term had not existed in the Polish language. It is hard or even impossible to find any women in the public sphere, in politics or among public figures.

The nineteenth century in Poland was the age of men. It was men that created history, wrote the works of literature and shaped the national iconic sphere; men defined the Polish symbolic canon and the social area, which was being suppressed by the partition authorities. Women at that time lived in the concealment of the private sphere - at home, by their men and under their protection. Paradoxically speaking, within this men's world, the role to be played by women was surprisingly large. The bloody armed uprisings and the state of permanent threat to the physical continuity of the nation and the risk of a loss of national identity forced upon the nineteenth-century Polish women, some kind of a "silent" emancipation. When their fathers and husbands went to war, it was the women that bore the responsibility for the families - for their safety and survival. When the men emigrated or were exiled to Siberia or sentenced to many-years imprisonment, it was the women that had to teach the patriotic canon to their sons ${ }^{2}$. This role is embodied in the figure of Mother Poland presented in the Romantic literature. The figure was

1 Grażyna Borkowska, Cudzoziemki. Studia o polskiej prozie kobiecej, Warszawa 1996; Jadwiga Zacharska, O kobiecie w literaturze przełomu XIX i XX wieku, Białystok 2000.

2 Kobieta i świat polityki. Polska na tle porównawczym w XIX i na pocz. XX w., pod red. Anny Żarnowskiej i Andrzeja Szwarca, Warszawa 1994; Kobieta i spoteczeństwo na ziemiach polskich w XIX wieku, pod red. Anny Żarnowskiej i Andrzeja Szwarca, Warszawa 1995. 
definitely sacralised and dignified, yet in its monumental pathos, it deprived women of their humanity by establishing an exorbitant ideal which imposed obligations difficult to meet, limiting the freedom and authenticity of life choices and spontaneity of experiencing marital and maternal love. Another interesting issue: work for women. One of the standing watchwords of British suffragettes became a platitude in Polish reality - self-reliance and the ability to maintain a family were the necessary conditions to survive in the absence of men. At the same time work for women was not treated as a positive value - for British women this was a guarantee of their social position and a synonym of independence, whilst in the Polish conditions, where the desired ideal was a traditional stabilization within a family, professional work was but a forced necessity.

To generalize the issue a bit, within the Polish cultural context, the phenomena which might be regarded as equivalent to those characteristic to Western Europe, were definitely different in their form. In Poland, the modernization processes were not only slower, but also were generally perceived as a threat to the national identity. The conservative mindset was considered to be a kind of patriotic obligation, a declaration to preserve the Polish character.

The very special history of Poland in the nineteenth century, its exceptional political and social situation had a significant influence on both creation of literary portraits of women and also on the social perception of the first symptoms of emancipation attitudes. It might be said that practically, until the period of modernism, female characters were pushed into the background of history, perceived as a solely male domain. Profound, intriguing and first of all, vivid portraits of women came as late as in the masterpieces of the Polish prose of the 1880s and 1890s (B. Prus, H. Sienkiewicz, E. Orzeszkowa, W. St. Reymont) and in the fin-de-siècle poetry ${ }^{3}$.

The work which seems to be the pioneer in the revolutionary change of the status of women in Polish literature is the exceptional novel written by Józef Ignacy Kraszewski titled: Szalona [Mad Woman] (1882). It is not the occasion to ponder upon the paradoxes around this novel - its author is generally regarded as a traditionalist and "friendly bore"; for some the novel was an exaggerated picture of the life of youngsters in Kiev, whilst for others it was an implied polemics with the Warsaw Positivists ${ }^{4}$. For us it is important that the story told

3 Maria Podraza-Kwiatkowska, Młodopolska femina. Garść uwag, w: Ciało i tekst. Feminizm w literaturoznawstwie - antologia szkiców, red. Anna Nasiłowska, Warszawa 2001; Krystyna Kłosińska, Ciało, pożądanie, ubranie. O wczesnych powieściach Gabrieli Zapolskiej, Kraków 2000.

4 Karol Wiktor Zawodziński, „Kobieta wyzwolona” w powieści Kraszewskiego, w: Opowieści o powieści, oprac. Czesław Zgorzelski, Kraków 1963. 
by Kraszewski, may be defined, with some simplification, as a study of "nihilist

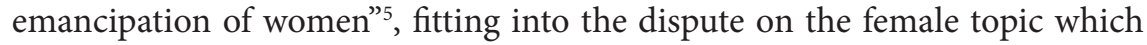
became a burning issue in the second half of the $19^{\text {th }}$ century.

The story of the title character - Zonia Raszkówna, seems to be the opposite of the story of a kind Polish young lady from a noble family. Kraszewski takes the popular pattern of two sisters (Zosia and Madzia), who, having been orphaned after the death of their parents are taken care of by two different families. Madzia finds herself in the traditionalist family of Dorohubowie, whereas Zosia - stays with the people, whose surname - Ozereńko suggests that they might be Russians. What is more important, though, is the fact that the disorderly life of that family and the chaos of their values leads to breaking the ties with her own family and the community tradition, and first of all opens for Zonia (not Zosia any more) a dangerous new world of modern ideas. This new reality is represented by the students of Kiev. This city was distant for the Poles of those times, yet, because of the large colony of Polish students there, very close at the same time. The distance, in terms of geography and ideology was large, as the city was dominated by the Russian elements, yet the memory of the old eastern borderlands of Poland brought it much closer. This Kiev became the scene of Zonia's "fall". She has been infected with the Russian free-thought, rejecting the old traditions and rights, she wants to live her own life, make her own choices without following the obligations and tradition. Her orphanhood gives her a sense of anarchistic freedom, therefore she makes one transgression after another: she takes up studies, breaks the social rules about what is appropriate and what is not for a high-born young lady: initially this was only about friendly disputes with other students, a life in the community of young people and finally, an overt atheism and sexual promiscuity ${ }^{6}$.

This seductive revolutionist turns out to be dangerous in a twofold manner - she breaches the world of patriarchal values, spreading the moral decay, capturing the affection of many men (including the honest Ewaryst), but also she "depraves" Kraszewski himself. The novel is intended to be a simple condemnation of women's emancipation, illustration of the threats for the social order which result from the violation of the centuries-long laws regulating the position of a woman in a society, finically changes into a fascinating story of the desire of knowledge, the spirit of rebellion, a poignant need of independence and woman's quest to be a fully-fledged human being.

5 Aleksander Zyga, „Szalona” - zamierzony pamflet na nihilistyczna emancypacje kobiet, „Rocznik Komisji Historyczno-literackej” XVII, 1980.

6 More see: Mateusz Skucha, Ładni chłopcy i szalone. Męskość i kobiecość w późnym pisarstwie Józefa Ignacego Kraszewskiego, Kraków 2014. 
The ambivalence of this strange novel consists in the fact that the main character, designed to be an anti-heroine, gains respect in the eyes of the readers. Zonia gets out of Kraszewski's control as her charismatic persona leads the writer towards the mysteries of female corporeality and emotionality, whilst the story itself, commenced with a moralistic overtone, changes into a tale of a heroic struggle for freedom and desperate attempts of self-fulfilment. Zonia's story cannot lead to a happy end, yet is not the docile Madzia the real loser in this story? Although the girl would obey the imperatives of the tradition, she would also experience the breakdown of the world - she would not win the heart of the beloved man, neither will she save the peace of the nobility's nest and finally she will not build a better life for herself. Zonia, in turn, who, in the intention of the author, was meant to be a warning against the madness of freedom, with her uncompromising mindset and noble magnanimity takes up the role of the leading character in the story - she eludes categorical evaluation, being the personality type which attracts and repels at the same time.

Kraszewski, condemning nihilism, sympathizes with the nihilist - the fatalism of her individual fate becomes the symbol of the fate of the whole generation. The writer unveils the mystery of the destructive upsurges - he understands that their source is the desperate sense of loneliness, spiritual emptiness of the young generation and the consequences of the fear resulting from the nihilist realization of "the empty heaven" - "heaven with no God". Zonia, speaking of her orphanhood, perceives it as a metaphor of her own fate, yet also the stigma of a modern man: a lost wanderer, truth seeker, a man who has lost the calm and humble faith of his fathers ${ }^{7}$. Yet her womanhood becomes her advantage and not a curse. Her awareness of women's inferiority within the society lends credibility to her rebellion against the principles of the oppressive male world; her awoken emotionality justifies the empathy for others, finally, the awareness of her own beauty gives her advantage over the crowd of men in love with her, liberating her from the passivity, traditionally attributed to women.

Zonia, with despair, repeats the noble gesture of the Romantic rebels: she struggles with the world, and, in some sense also with God (this these explores the subject of the desire and inaccessibility of death). Her destructive anger and a need of rebellion contain something noble and honest. The beautiful nihilist differs very much from the characters disgraced in the novel: the ideologist Jewłaszewski and vain madam Heliodora. That is why Kraszewski allows Zonia

Magdalena Rudkowska, Kraszewski wobec Rosji. Próby komparatystyczne, Warszawa 2009, taż, Nihilizm po polsku. Prolegomena do lektury „Szalonej”, w: Nihilizm i historia. Studia z literatury XIX i XX wieku, pod red. Mikołaja Sokołowskiego i Jarosława Ławskiego, Białystok-Warszawa 2009. 
to save her dignity - he does not make her end up in the gutter like a fallen woman (which would strengthen the effect of probability), but lets her fight among the Communards in Paris, and, after the defeat, carry on fighting in her writings in republican journals. The writer condemns the attitude of his character, and sometimes he distances himself from her ideas, yet he retains some respect towards her life choices, as if realising that her story is a prelude of the changes to come. Kraszewski's Zonia is therefore the child of her own times, predicting the anxieties of the decadents, the bitterness of the pessimism of Schopenhauer's readers and the oncoming time of social revolution and female's emancipation.

The readers of Kraszewski's times did not want to read Szalona, as a work full of empathy and reflection of the fatalism of fate. The issue of inevitability of nihilism, as the extreme stage of rebellion and a kind of crisis in the history of civilization, taken up by Kraszewski, justifies the symbolic meaning of Zonia's character. The readers then were closer to the black-and-white distinctions of the biased, moralistic novels of that time. The only disputable issue remains - where to look for the writer's intentions? Eliza Orzeszkowa, representing a progressive option, wrote about Kraszewski's backwardness and his narrow-minded conservative beliefs, seen in Szalona:

In my opinion, this novel is an act against the society, art and common sense. How come?

So this is the type of a modern woman in love with learning, asking for her individual and human rights! And the opposition of this anathematised type is Madzia - a cry-baby, silly as a goose, boring as hell and old-fashioned! (...) Really, why did he contrast university, academics' disputes, when such "mad woman" could be found in every red-light district? Do we need emancipation and universities for the life that this "mad woman has"?"

Orzeszkowa's indignation should be explained with the dangerous, in her opinion, identification of the idea of women's emancipation with the libertinage of the character displayed in Kraszewski's story. Orzeszkowa did not hesitate to call her a "prostitute", because she did not want and could not approve of the fact that the price for intellectual freedoms and the right to learn and to work (i.e. the watchwords of suffragettes and emancipationists proclaiming political and economic liberties) turns out to be the rejection of generally accepted social conventions and the obligation "towards the Polish sanctified family" imposed by tradition one every woman.

8 E. Orzeszkowa, List do Walerego Przyborowskiego z 14.01.1880, w: Listy nieznane: Eliza Orzeszkowa do Walerego Przyborowskiego, oprac. M. Romankówna, „Prace Polonistyczne" 1947, nr 5, s. 136-137. Za: M. Skucha, dz. cyt., s.33. 
What seems to be equally interesting are the voices of those critics who saw Szalona, as a literary work-out of the disturbing social phenomena which could be observed in the Polish educated milieus at Russian universities. This problem was captured with great accuracy by Marian Zdziechowski in his work, Wptywy rosyjskie na dusze polska [Russian Influence on Polish Soul] from 1920. In his summary of the period of partition, from the perspective of the experience of the Bolshevik revolution, this careful observer pays attention to the ethical devastation which was made due to the Russian despotism. One of the most dangerous effects of the action of the "Russian pattern" was maximalism - the policy of deprivation of freedom pursued by the Tsars released extreme anarchistic attitudes, the terror of the authorities led to an uncompromising rebellion, despotism bred nihilism ${ }^{9}$.

These observations seem to be a valuable comment to the bewilderment accompanying Polish disputes over women's emancipation. The voice which seemed to be the strongest, apart from traditionalist views directed against all novelties, was represented by those who, sensing the need of changes, emphasized the risk for Polishness coming from taking emancipation models from Russian circles. Kraszewski's Zonia became a dangerous example of extremism, an example of self-destruction - the freedom that she sought turned out to be chaos and destruction; it was merely a negation. Her character unleashed fear, because it excluded any possibility of compromise, proving that women, struggling for freedom, do not stop halfway. What is worse, the model of women's emancipation understood in such a way, did not come from the admired Western civilization, but from the hated and despised Eastern occupant.

Zonia's “madness” expressed in the novel's title - as Magdalena Rudkowska stresses - becomes something more than the metaphor of "Russia as Revolution", "Woman as Revolution" or "Woman as Nature"10 described by Maria Janion. The madness seems to be the metaphor of the advancing modernity, and the face of a rebellious woman gains the significance of a symbol. The field of association, accompanying the figures of Polish nobility women undergoes a radical change. The figures of women-guardians of hearth and home, protective angels and diligent housewives, captured in literature, passed into oblivion. They were replaced by the wrathful Egerias, "arsonists" putting fire to the old world, revolutionists and

Mikołaj Sokołowski, Stereotyp Rosjanina-nihilisty w twórczości Józefa Ignacego Kraszewskiego, w: Nihilizm i historia. Studia z literatury XIX i XX wieku, pod red. Mikołaja Sokołowskiego i Jarosława Ławskiego, Białystok-Warszawa 2009.

10 Magdalena Rudkowska, Kraszewski wobec Rosji, dz. cyt., s. 139. Zob. też Maria Janion, Szalona, w: Zdziwienia Kraszewskim, pod red. Marty Zielińskiej, Warszawa 1990, s. 18. 
nihilists. Maidens from nobility manors, struggling for emancipation become the symbols of rebellion and the rejection of traditional values.

This process, seen on the pages of literary works turns out to be parallel to the phenomena in social life. Polish emancipation paths, after the preliminary stage of "enthusiasts", impoverished nobility women who (like Narcyza Żmichowska, Zofia Węgierska or Bibianna Moraczewska) fought for women's rights as governesses, journalists and writers; finally led to the extreme attitudes of anarchists (Zofia Klimańska), nihilists, terrorists (Faustyna Morzycka) or forgotten heroines of revolution in 1905 's.

\section{References}

Borkowska Grażyna, Cudzoziemki. Studia o polskiej prozie kobiecej, Warszawa 1996; Jadwiga Zacharska, O kobiecie w literaturze przełomu XIX i XX wieku, Białystok 2000.

Kobieta i świat polityki. Polska na tle porównawczym w XIX i na pocz. XX w., pod red. Anny Żarnowskiej i Andrzeja Szwarca, Warszawa 1994; Kobieta i społeczeństwo na ziemiach polskich w XIX wieku, pod red. Anny Żarnowskiej i Andrzeja Szwarca, Warszawa 1995.

Podraza-Kwiatkowska Maria, Młodopolska femina. Garść uwag, w: Ciało i tekst. Feminizm w literaturoznawstwie - antologia szkiców, red. Anna Nasiłowska, Warszawa 2001; Krystyna Kłosińska, Ciało, pożądanie, ubranie. O wczesnych powieściach Gabrieli Zapolskiej, Kraków 2000.

Zawodziński Karol Wiktor, „Kobieta wyzwolona” w powieści Kraszewskiego, w: Opowieści o powieści, oprac. Czesław Zgorzelski, Kraków 1963.

Zyga Aleksander, „Szalona” - zamierzony pamflet na nihilistyczną emancypację kobiet, „Rocznik Komisji Historyczno-literackej” XVII, 1980.

Skucha Mateusz, Ładni chłopcy i szalone. Męskość i kobiecość w późnym pisarstwie Józefa Ignacego Kraszewskiego, Kraków 2014.

Rudkowska Magdalena, Kraszewski wobec Rosji. Próby komparatystyczne, Warszawa 2009, taż, Nihilizm po polsku. Prolegomena do lektury „Szalonej”, w: Nihilizm i historia. Studia $z$ literatury XIX i XX wieku, pod red. Mikołaja Sokołowskiego i Jarosława Ławskiego, Białystok-Warszawa 2009.

Orzeszkowa Eliza, List do Walerego Przyborowskiego z 14.01.1880, w: Listy nieznane: Eliza Orzeszkowa do Walerego Przyborowskiego, oprac. M. Romankówna, „Prace Polonistyczne” 1947, nr 5..

Sokołowski Mikołaj, Stereotyp Rosjanina-nihilisty w twórczości Józefa Ignacego Kraszewskiego, w: Nihilizm i historia. Studia z literatury XIX i XX wieku, pod red. Mikołaja Sokołowskiego i Jarosława Ławskiego, Białystok-Warszawa 2009.

Rudkowska Magdalena, Kraszewski wobec Rosji, dz. cyt., s. 139. Zob. też Maria Janion, Szalona, w: Zdziwienia Kraszewskim, pod red. Marty Zielińskiej, Warszawa 1990. 